\title{
Towards Smart Village: A Case Study of Genteng Village Development in Sumedang, West Java, Indonesia
}

\author{
Sri Fatimah 1,* (i) Mochamad Gunardi Judawinata 1, \\ Mochamad Nursiyam Barkah 2, (D) Lucyana Trimo 1, (D) and Yosini Deliana 2 \\ ${ }^{1}$ Department of Agricultural Socio-Economics, Faculty of Agriculture, \\ Universitas Padjadjaran, 45363, Jatinangor, West Java Province, Indonesia \\ 2 Department of Applied Geology, Faculty of Geological Engineering, \\ Universitas Padjadjaran, 45363, Jatinangor, West Java Province, Indonesia \\ * Corresponding Author: sri.fatimah@unpad.ac.id
}

\section{ARTICLE INFO}

\section{Publication Info:}

Research Article

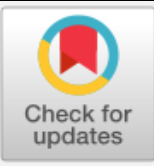

How to cite:

Fatimah, S., Judawinata, G., Barkah, M. N., Trimo, L., E Deliana, Y. (2020). Towards Smart Village: A Case Study of Genteng Village Development in Sumedang, West Java, Indonesia. Society, 8(2), 663-676.

DOI: $10.33019 /$ society.v8i2.264

Copyright (C) 2020. Owned by Author(s), published by Society

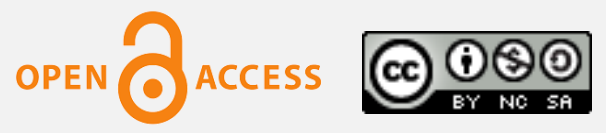

This is an open-access article.

\section{License: Attribution- NonCommercial-ShareAlike (CC BY-NC-SA)}

\begin{abstract}
This research aims to identify the prospects and challenges for implementing smart villages using a case study of Genteng Village in West Java, Indonesia, according to the sustainable development perspective and the enabler factors of socioeconomic factors, village's technology, and environmental aspects. This research uses a qualitative approach to assess the potencies and challenges from social, economic, environmental, and infrastructure perspectives. This research conducts a field survey with in-depth interviews and observation in Genteng Village, Sukasari Sub-district, Sumedang Regency, West Java Province to tap the information needed. Interviews with stakeholders were conducted with informants representing the rural stakeholders consisted of village official government, village local champion/leader, and farmer group representatives. Researcher involvement in nearly two years in regular visits and observations before this research has enriched and validated the information obtained. This research found prospective local social capital components and economic potencies to develop using the smart village framework. Environment and infrastructure are relatively still the challenges to be overcome towards the smart village. This research concludes that Genteng Village is on the right track, though early-stage to develop as a smart village. External factors, mainly information and communication technology, will be one of the main driving factors for optimism in implementing a smart village in Genteng Village.
\end{abstract}

Copyright ( 2020 . Owned by Author(s), published by Society. This is an open-access article under the CC-BY-NC-SA license. https:// doi.org/10.33019/ society.v8i2.264

663 
Received: November 14, 2020;

Accepted: December 28, 2020;

Published: December 30, 2020;
Keywords: ICT; Local Potential; Rural Development; Smart Village

\section{Introduction}

Farmers must be prepared to face an era of openness and an era of disruption and meet quality standards of market demand. For this reason, farmers need to master information to facilitate them in making important decisions related to their agriculture business, select markets, and ensure continuous supply from upstream to downstream to support the independence and sustainability of food supply. The flow of information has also become very important for agriculture in adapting to climate change. Appropriate decision-making requires farmers to access information and knowledge in dealing with the risks of climate change (Tetteh et al., 2019). Therefore, rural communities that usually lack the knowledge to develop their potential and solve their challenges need to be facilitated to do better business in agriculture and better life in general.

The smart village concept has emerged internationally as a rural development program to optimize rural potencies and increase information and communication technology utilization to achieve better community welfare. For example, the smart village's introduction potentially strengthens the rural economic structure from the economic perspective, creating new leading sectors to produce products that benefit and be more competitive (Pramanik et al., 2017). Technology, especially ICT, is expected to narrow the gap between goals and achievements, especially in the rural context. Therefore, it is essential to recognize and direct the developing villages to find patterns or models of smart villages by optimizing agricultural resources to accelerate rural socio-economic development in a sustainable manner (Shukla, 2016).

This research aims to identify and assess Genteng Village's prospects in West Java to develop a smart village based on facts and village stakeholders' expectations. By identifying the village's characteristics, various community activities that describe the current conditions, and the profiles of community socio-economic-environmental activities that support village development, this research tries to conclude what prospect of the smart village developed Genteng Village as a case study. It is hoped that this research can identify prerequisites and a village's process to become a smart village.

\section{Literature Review}

Information is an essential factor that is needed by each individual, including farmers. For example, the information benefits gain by Garut tangerine farmers in West Java is not only the new technicality in farming. However, also farmer started to realize that mastery of information has changed the fact that financial capital is no longer the main requirement for building a business. However, instead, the information is the main factor (Fatimah \& Prawita, 2015). The existence of ICT provides benefits in increasing literacy level knowledge, reducing the digital divide, and improving rural communities' economy (Kamarudin et al., 2019). ICT is no longer strange to the daily lives of rural communities, including for agricultural purposes. The ICT utilization is still not optimal because many of its uses are for prestige purposes, so that modern impressions are not out of date. ICT has reduced the habit of interaction in the village and activities to be more individual or exclusive. For this reason, it is necessary to encourage more extensive use of ICT and at the same time increase benefits for more positive goals.

The concept of smart villages aimed to help villagers, especially the majority of the inhabitants, mostly farmers, to utilize the facilities generated by ICT development. The Smart

Copyright (C) 2020. Owned by Author(s), published by Society. This is an open-access article under the CC-BY-NC-SA license. 
village concept may be the movement of reforms towards a fair and just society utilizing resources (Shukla, 2016). A village is an area where the community is characterized by sparse population/little density, inherited social characteristics, generally non-intensive economic activities such as in cities, and many more characteristics. An intelligent village can be connoted as a village whose service function as a village can occur effectively and efficiently, performs better, especially with the development of the quality of knowledge, communication, and social infrastructure (Somwanshi et al., 2016). Smart villages are characterized by, among others, knowledgeable farmers as individuals and groups, using information and communication technology, and savvy institutions and facilities (Viswanadham \& Vedula, 2010). The utilization of technology both in general and ICT technology is becoming a supporter of smart villages (Shcherbina \& Gorbenkova, 2018). Likewise, institutional capacity and capability are essential to accommodate and facilitate the will and increase farmers' ability and village communities (Nidumolu et al., 2020).

Following the sustainable development paradigm, every country pursues to achieve its development goals following the principle of Sustainable Development Goals (SDGs), an internationally accepted development paradigm as a continuation of Millennium Development Goals (MDGs). All countries try to direct development efforts to align with these goals at various scales from national to urban and rural areas. Each level has its prospects and challenges. Akgün et al. (2014) discussed at least some factors that support sustainable development in rural areas, namely social, economic, environmental, and innovation capabilities and infrastructure factors. The smart village concept is an effort to realize sustainable development in rural areas by utilizing the village's potential, especially the agriculture sector dominant in a rural setting (Guzal-Dec, 2018).

The social conditions of the population have a vital role in creating smart villages. Human resources who have adequate capacity and capability will be able to manage and utilize existing resources optimally. The age factor will limit farmers' ability to adopt technology in developing farming (Okwu \& Umoru, 2009). Younger ages usually are more familiar to get used to with information technology (Vaishar \& Št'astná, 2019). Besides education level, age and gender influence technology's application (Liu \& Zhang, 2011). Awareness of access to information technology is influenced by access to higher education (Baruah \& Mohan, 2018). The sociodemography will be very important to be identified in the development of smart villages. It is a kind of social capital for the development of a smart village.

Among the rural economy, the challenge is the relatively static economic structure, low value-added creation, lack of entrepreneurship, inadequate promotion and marketing, and less competitiveness of the rural economy (Garcia-Alvarez-Coque et al., 2020). Innovation in the rural economy may increase rural economic viability through diversification (de Roest et al., 2018). Economic factors of the rural need to be optimally exploited to pursue better living conditions ( $\mathrm{Tu}$ et al., 2018).

Every area is location-specific because of its natural and geographical conditions. This could be prospective but also challenges that need to be managed wisely and smarter. Environmental resources may have value for attraction, but it may also contain challenges mainly if it is disaster-sensitive to external forces (Chatterjee \& Mitchell, 2013). Wise environment management is among the concept of smart village's offer to rural people (Sachs \& George, 2015).

Smart village is inseparable from information technology infrastructure and facilities, as this will support various activities of rural communities towards more efficient use of resources. Thus, it is necessary to increase information technology to easily access every service such as

Copyright (C 2020. Owned by Author(s), published by Society. This is an open-access article under the CC-BY-NC-SA license. https://doi.org/10.33019/society.v8i2.264

665 
village database, health, agriculture, marketing, and environment. For this reason, it is necessary to improve infrastructure and facilities to support the use of information and communication technology (Ahuja, 2011). A consistent commitment has been started, especially from the local government. It will become a political will and maybe the first important step in developing rural human resources using ICT (Lam \& Ho, 2010).

\section{Research Methodology}

This research uses a research design combination of explanatory research and descriptive research. This research design combination results in more explaining, and the aim is to describe the research object's phenomena and characteristics (Rubin \& Babbie, 2010). This research conducts a field survey with in-depth interviews with community representatives and observation in Genteng Village, Sukasari Sub-district, Sumedang Regency, West Java Province to tap the information needed.

The research was conducted in Genteng Village, Sumedang Regency, West Java province as the chosen village and will be prepared as a smart village. This village is quickly affected by new development centers, including the Jatinangor Campus complex and the Bandung Sumedang corridor's rapid development. The first phase of this research examines and collects information, data, and intensive observations in the field, especially in examining how stakeholders respond to smart villages' concept. As representatives of the stakeholders, these research' informant selectants represented the community's main components upon a local village government's suggestion. Based on the village government's approval, this research selects the following informants that, to some extent, are interested in the concept of a smart village. This research interviews the two farmer groups' heads in Genteng Village head and two group members as farmers' representatives. Two local champions are selected to represent local non-government leaders. The rest are two village government officers consisting of the Village Head and an officer dealing with the local administration program. The research was conducted at the end of 2018 for about three months, from September until mid-November.

\section{Results and Discussion}

\subsection{Profile and Characteristics of Genteng Village}

Administratively, Genteng Village is one of the seven villages in the Sukasari Sub-District, Sumedang Regency, located 3 kilometers north of the Sukasari Sub-District. Genteng Village is located at an altitude of 1200 above sea level with an area of $\pm 1,300$ hectares. The temperature average in Genteng Village is $30^{\circ} \mathrm{C}$. The climate of Genteng Village, like other villages in the territory of Indonesia, tropical climate with dry and rainy seasons. It has a direct influence on cropping patterns in Genteng Village. The seasons of an area is very influential for plant growth and livestock survival. Besides, the geographical condition of Genteng Village is in the hills area (Sumedang Tandang, n.d.). Genteng Village is a village with a population of 6,139 people consisting of 2,219 families divided into six hamlets with a total male population of 3,158 and a female population of 2,988 (Kantor Desa Genteng, 2018).

Table 1. Total Population by Hamlet in Genteng Village

\begin{tabular}{cccccc}
\hline Hamlet I & Hamlet II & Hamlet III & Hamlet IV & Hamlet V & Hamlet VI \\
\hline 1,256 & 1,203 & 673 & 1,318 & 902 & 807 \\
\hline
\end{tabular}

Source: Kantor Desa Genteng (2018)

Copyright (C) 2020. Owned by Author(s), published by Society. This is an open-access article under the CC-BY-NC-SA license. 
Towards Smart Village:

A Case Study of Genteng Village Development in Sumedang, West Java, Indonesia

Table 2. Total Families by Hamlet in Genteng Village

\begin{tabular}{cccccc}
\hline Hamlet I & Hamlet II & Hamlet III & Hamlet IV & Hamlet V & Hamlet VI \\
\hline 422 & 439 & 242 & 477 & 302 & 337 \\
\hline
\end{tabular}

Source: Kantor Desa Genteng (2018)

The population age composition of Genteng Village is dominated by the working-age population (aged 15 - 59 years), as many as 4,618 people, or 76.9 percent of the total population of Genteng Village. A large working-age population will provide opportunities for smart village development.

Table 3. Population by Age Group and Gender in Genteng Village

\begin{tabular}{cccc}
\hline Age Group & Male & Female & Total \\
\hline $0-4$ & 137 & 134 & 271 \\
$5-9$ & 165 & 157 & 322 \\
$10-14$ & 205 & 203 & 408 \\
$15-19$ & 298 & 289 & 587 \\
$20-24$ & 405 & 401 & 806 \\
$25-29$ & 455 & 454 & 909 \\
$30-39$ & 482 & 479 & 951 \\
$40-49$ & 335 & 331 & 666 \\
$50-59$ & 352 & 347 & 699 \\
$>60$ & 230 & 231 & 461 \\
\hline
\end{tabular}

Source: Kantor Desa Genteng (2018)

The village people have a close kinship. That is, there is strong cooperation among the village people in various activities. For example, in social activities, development activities both by individuals or government programs. In terms of education, the community's social condition is increasing compared to the previous year. Parents' level of awareness to continue their children's education to a higher level is very dominant. In the past few years, almost all elementary school graduates continue to junior high school and so on as follows:

Table 4. Total Population by Education Level in Genteng Village

\begin{tabular}{ccccc}
\hline Preschool & $\begin{array}{c}\text { Elementary } \\
\text { School }\end{array}$ & $\begin{array}{c}\text { Junior High } \\
\text { School }\end{array}$ & $\begin{array}{c}\text { Senior High } \\
\text { School }\end{array}$ & Bachelor \\
\hline 99 & 921 & 135 & 78 & 56 \\
\hline
\end{tabular}

Source: Kantor Desa Genteng (2018)

The people of Genteng Village generally work as farmers. Agriculture is the primary sector in people's income in Genteng Village. The villagers' income source varies as follows: 
Towards Smart Village:

A Case Study of Genteng Village Development in Sumedang, West Java, Indonesia

Table 5. Total Population by Livelihood in Genteng Village

\begin{tabular}{cccccc}
\hline Farmer & Breeder & Laborer & $\begin{array}{c}\text { State Civil } \\
\text { Apparatus }\end{array}$ & $\begin{array}{c}\text { Private } \\
\text { Employee }\end{array}$ & Trader \\
\hline 2,856 & 1,332 & 1,002 & 68 & 76 & 305 \\
\hline
\end{tabular}

Source: Kantor Desa Genteng (2018)

In terms of infrastructure, Genteng Village is quite accessible from transportation infrastructure. Even though it is in a hilly area, the access road is relatively good with the hardened and paved roads. Access to local scale business and trade centers is relatively smooth, especially to bring village products to the nearest market. From the energy infrastructure, Genteng Village is one of the villages that have reached the full electrification level so that energy problems are no longer a problem. Electrification has also driven village progress significantly, especially access to clean water, education, communication technology, and various support for creating business opportunities worldwide (Anderson et al., 2017).

\subsection{Potential of Genteng Village and Its Challenge as a Smart Village}

\subsubsection{Social Aspect of Population}

In terms of education as an indicator of social progress, the social conditions of the people of Genteng Village were categorized as excellent. The awareness of getting a better education for the younger generation has been embedded in the community. Awareness that education is the key to achieving a better status has become hold on most parents who want their children's education better than they do. Both academic and social intelligence will be determined mainly by the success of formal education from the community. Likewise, socialization and introduction of new ideas and programs from outside, especially the government will be easier if the community has the right level and capacity for adoption that can only be obtained through education.

From the social aspect of the population, Genteng Village can support smart villages' development. Working-age population dominates Genteng Village. This will facilitate the government in socializing or implementing programs related to smart villages because, at a working-age, the community can still produce a product and still work. The Genteng Village community still has village communities' characteristics that still cooperate personally and in government activities. This becomes very important because a smart village need a collective attitude from the community to support each other in managing the village's resources. One of the farmer groups' heads stated directly that the village community's cohesiveness was still high and agreed by the other farmer group heads in other interview sessions.

From the social aspect of the population, Genteng Village can support smart villages' development. The working-age population dominates Genteng Village. This will facilitate the government in socializing or implementing programs related to smart villages because, at a working-age, the community can still produce a product and still work. The Genteng Village community still has village communities' characteristics that still cooperate personally and in government activities. This becomes very important because smart villages need a collective attitude from the community to support each other in managing the village's resources. One of the farmer groups' heads stated directly that the village community's cohesiveness was still high and agreed by the other farmer group heads in other interview sessions.

Copyright (C) 2020. Owned by Author(s), published by Society. This is an open-access article under the CC-BY-NC-SA license. 
"The community around us is a group that is easy to mobilize mainly because of role models they still believe in, such as religious leaders, village heads, and certain figures" (interview with one of the heads of farmer groups, October 2018).

Advances in technology have facilitated efforts to intensify these values because it makes it easy to implement in every activity, especially in scale and speed. As users of communication tools, almost all villagers have been connected with mobile media, making communication easy among fellow villagers. The challenges in developing the smart village in Genteng Village are related to the quality of its human resources. People with low levels of education currently dominate. There is around 46.4 percent of the total population who have a low level of education (elementary school).

In comparison, the population with a high education level (Bachelor) is only around 4.3 percent of the total population in Genteng Village. Education has a vital role in improving the quality of human resources. One of the factors influencing the digital divide is social and geographical factors (Syarifuddin, 2010). Awareness of access to information technology is influenced by access to higher education (Baruah \& Mohan, 2018). Access is crucial in understanding how information and communication technology as an intermediary media and how to make information and communication technology a platform in every positive activity that requires the thinking of people who have knowledge related to ICT. In addition, mobilizing the community certainly requires a particular strategy that cannot be generalized at all levels and population groups. For this reason, it needs to be considered so that smart village's development can be done with appropriate methods following the characteristics of the population in Genteng Village.

\subsubsection{Economic Aspect}

The agricultural sector dominated the economy of Genteng Village. The agricultural land area in the Genteng Village is 596 hectares or 45 percent of the village administrative area. This land area consists of 314 hectares of paddy fields and 282 hectares of non-paddy fields (Kantor Desa Genteng, 2018). In managing their agriculture activities, the farmers establish several farmer groups. However, the most prominent are two farmer groups, namely Pager Kamulyan Farmer Group and Chrysanthemum Women Farmers Group.

These farmer groups began to innovate by relying on farmland and developing flower cultivation as an agricultural commodity, such as chrysanthemum cultivation. This is an opportunity for villagers to improve their economy because their income is higher than vegetable cultivation. Genteng Village is suitable for flowering because its position and height are suitable for flower cultivation. The optimism of the farmer group was expressed by the other head of the farmer group as follows:

"We are optimistic that the farmer groups here and farmer groups in other villages will be pleased and helped in developing agricultural products, especially if technology can help us from land management to crop selection and marketing" (interview with one of the heads of farmer groups, October 2018).

The marketing efforts of flower products have also used ICT technology. Everything has been done using information technology, starting from order, delivery, and pricing, even at a practical and fundamental level. Farmer groups want a more modern and sustainable auction mechanism and interest information with a broader market network. However, due to the lack

Copyright (C 2020. Owned by Author(s), published by Society. This is an open-access article under the CC-BY-NC-SA license. 
of human resources, this is still an obstacle and a way forward. Land management and agricultural products for farmer groups in the village of Genteng still encounter various difficulties related to harvest and post-harvest technology.

Chrysanthemum Women Farmers Group is a group of women working on processing agricultural products, including pioneering efforts to optimize flower cultivation. Efforts to improve farmers' skills are still needed to increase farmers' and women farmers' capacity and capability to directly overcome this problem, increasing farmers' and women farmers' income. It is necessary to expand the market network so that agricultural products can be distributed more optimally. Extension agents from the regency government have been maximized in providing guidance and counseling. However, the limited personnel and time have resulted in a lack of effectiveness of extension agents in encouraging the village's economic potential.

"The economic potential, especially in rural farming, is vibrant and diverse, and we
want more added value than what we have been getting. Therefore, we encourage
community innovation as practiced by Chrysanthemum Women Farmers Group.
Unfortunately, we lack knowledge, and there is still limited counseling capacity to
support us" (interview with Head of Genteng Village, October 2018).

Improve the community's economy cannot be separated from the availability of infrastructure and facilities to support economic activities. At present, the condition of infrastructure and facilities in Genteng Village has not been evenly distributed in accommodating the marketing or transportation of agricultural products. Several hamlets still have difficulty in physical access. The inadequate public transportation makes it difficult for farmers who do not have transportation and increase production costs because they have to pay transportation costs. These constraints can be minimized by using information technology at the production, processing, and marketing levels. Information technology has a significant contribution and provides various benefits for farmers, and even provides savings in agricultural costs (Nidumolu et al., 2020). Therefore, through information technology, it is expected that rural communities' economies will increase.

\subsubsection{Environmental Aspect}

Geographically, Genteng Village is located in the western area of Sumedang Regency, whose geographical conditions are the highlands and hills. The agricultural sector is the main livelihood for the population in Genteng Village. Sustainable management of agricultural land and conservation of forest and water resources remain quite intensive challenges in Genteng Village.

In managing agricultural land, several Genteng Village people still use conventional methods, which exploit excessive land. The observations show that this community group's lack of awareness in implementing environmentally-friendly agriculture and efforts to protect and preserve forest areas and conservation is caused by a lack of knowledge in exploiting the existing natural potential.

"At the moment, there are several people who are still carelessly using hilly nature land that used to function for conservation, but now it is an agricultural area that has the potential to erode and damage nature" (interview with a local figure, November 2018).

Copyright (C) 2020. Owned by Author(s), published by Society. This is an open-access article under the CC-BY-NC-SA license. 
People only use agricultural land for cultivation. The use of eradicating pests and chemical fertilizers are still high. It is necessary to identify how people use the nature subresources' potential because it tends to damage nature if it is excessive. It is necessary to provide assistance and education to instill understanding in the village to use natural resources wisely by accommodating ecological aspects. It is hoped that with the increase of awareness, the smart village label will be increasingly realized for continues to encourage the sustainable development of all aspects of community life (Vignesh \& Priyan, 2018).

Awareness in managing environment-based village arises to develop the village as a tourist destination. The natural structure of hills and suitable plants turned out to be developed as one of the beauties of the village in terms of scenery so that it has the potential to attract local tourists to visit. It can only achieve if nature as a tourism resource is managed well and wisely. For this reason, village leaders and a group of activists have pioneered and campaigned to make their land available, tourist attractions, and the need to manage the environment and land more responsibly.

"We are not talkative, but the tourism potential in our village pretty much starts from agriculture combined with the beauty of nature starting to attract visitors around to enjoy the beauty of the countryside in our place. We want this activity to be more programmed and become one of the village's economic activities in the future" (interview with a village officer, October 2018).

\subsubsection{Information and Communication Technology (ICT) Infrastructure Aspect}

The telecommunications network in Genteng Village is quite good and adequate to meet their communication needs. The telecommunications network provides easy access for farmers to find information and innovate. The constraints of agricultural innovation and information that have been happening so far are expected to be reduced using information technology.

The utilization of information and communication technology (ICT) as a support for groups and smart villages' activities has begun using computer and telecommunications equipment. However, currently, it is still limited to mobile phones. The learning process in introducing ICT technology continues to run mostly to the older generation to understand and operate computers, start learning data entry and information, and simple business administration. Members of farmer groups who are old and with low education levels must learn computer technology to run farmer group operations and administrations. Previously, based on interviews with farmer group members, they did not understand how to operate computers. However, they are trying to learn and run standard computer operations.

Computer and telecommunications equipment's utilization intensity shows an efficient level for farmer groups to coordinate, find information, and market products. The existing communication tools also help every stakeholder in Genteng Village coordinate both in government affairs and agricultural land management matters. However, mobile phones have limitations when a system is needed to serve all citizens and groups' needs related to the various needs and services needed. ICTs can transform agricultural processes into intelligent processes. With the help of ICT-based services, a farmer can immediately seek advice in their language from agricultural experts (Pramanik et al., 2017).

"We have many children who have learned ICT. If it is necessary, we will ask the village to fund courses on ICT to help develop the village, the village administration

Copyright (C 2020. Owned by Author(s), published by Society. This is an open-access article under the CC-BY-NC-SA license. 
system, as well as matters relating to the economy, business and village agriculture" (interview with the local government officer, November 2018).

\subsection{Discussion}

The concept of smart villages refers to people in rural areas who build on existing strengths and assets and develop new opportunities (Zavratnik et al., 2018). The field observations show a high level of interest and interest in the concept of a smart village. Some stakeholders provide support in various forms, such as the form of a contribution of thought, energy, and budget to realize the concept of smart villages based on local potential through the idea of ecotourism villages. This idea arises, observing that other villages' experiences have proven that village development can be pursued through a product-based approach and local potential that has contributed to improving the family's economy while increasing the village government's original income.

In summary, it can be identified that the village of Genteng is still at the stage of treading smart villages. This can be seen from village community development's character and stages based on observation and interaction with villagers' various activities. It is seen that the capacity of people and community organizations in the village is critical and dynamic to develop themselves in line with the development and dynamics of development. The interviews results with informant selected in this research, they showed positive responses and full support. However, merely support is not enough without being supported by organizations and institutions in Genteng Village. Genteng Village has advantages, namely its inhabitants' high enthusiasm, seen from the resilience from various problems such as lack of capital and fluctuating selling prices. However, farmers are still loyal and passionate to develop flower farming in this village.

Increasing the capacity of community organizations and formal village government institutions, at least in providing support for smart villages, still requires structuring that is more focused on smart villages' goals. Various forms of activities to strengthen the Genteng Village human resources' capacity and capabilities such as training in management/organizational governance, encouraging the use of ICT, encouraging restructuring or reorganization, and increasing participation in the village policy-making process. No less significant is the strengthening of the Genteng Village local government's capacity in realizing smart villages as a movement and one of the pillars and supporters of smart villages. Moreover, the Genteng Village government ensures smart village ideas or independent seed program proposals were included in the 2019 village budget. Specifically, the village government ensures the implementation of support activities, especially in support of local products' development, namely the procurement of chrysanthemum flower seeds as superior village products.

Although it is still partial and fragmented, the potential and efforts to become a smart village already exist. What is needed is how these efforts can be synergized into an integrated movement. Smart villages become the norm for village development for the future (van Gevelt et al., 2018). Through smart villages, the village will become an independent village (Vignesh \& Priyan, 2018). Realizing Genteng Village to be a smart village is a target for both the government and villagers in facing challenges in the future. The learning process looks evident in terms of economic, social, and environment to make this region a developed village even though the challenges are not easy and few. Strengthening village potential and sustainably managing villages has been driven by the will to become a smart village. The effort began with

Copyright (C 2020. Owned by Author(s), published by Society. This is an open-access article under the CC-BY-NC-SA license. 
the empowerment of the farming community, youth, women, and all interested parties to develop existing potentials but sustainably, as has been done elsewhere (Vaishar \& Št'astná, 2019).

There are still many aspects that need to be improved in its management. Of course, technological advances, especially ICT to support all these efforts, will benefit much in advancing and promoting rural development in Genteng. Improvement of the practice of sustainable agricultural land management, ease of access to services such as health and education services, including the application of ICT in rural tourism programs (Bahtiar et al., 2020). Smart village development is impossible if it is not accompanied by determination and the ability to manage local potential from all perspectives, including external factors. Genteng Village can utilize campus resources to provide technical assistance and consultation and other formal mechanisms through a triple helix collaboration scheme between universitiesgovernment-the business sector. The Government of Sumedang Regency should support any necessary policies, mainly in infrastructure.

\section{Conclusion}

Smart village development in rural areas, especially Genteng Village, is very much needed nowadays, as an effort to improve the quality of life for rural communities. It can provide space for the community to increase its potential and use resources effectively and efficiently. Advances in information and communication technology should be used for rural development in education, business, health, and participation to improve rural communities' welfare. Innovation using ICT may be applied at a reasonable cost (Phiri et al., 2018). A smart village is also expected to reduce the number of rural residents to urban migration, and new jobs are expected to emerge due to innovation from the village community.

Developing smart villages is prospective, where people can utilize information and communication technology to support agricultural and social activities. The development of the Genteng Village as a smart village has several problems that require the cooperation of every stakeholder, the government, academics, entrepreneurs, and the village community itself. Genteng Village already has all components to optimize. The local system's social, economic, and infrastructure characteristics tend to be positive towards smart village development in Genteng Village.

There are still many aspects that need to be improved in its management. Of course, technological advances, especially ICT to support all these efforts, will benefit much in advancing and promoting rural development in Genteng. Improvement of the practice of sustainable agricultural land management, ease of access to services such as health and education services, including the application of ICT in rural tourism programs (Bahtiar et al., 2020). Smart village development is impossible if it is not accompanied by determination and the ability to manage local potential from all perspectives, including external factors. Genteng village can utilize campus resources to provide technical assistance and consultation, and other formal mechanisms through a triple helix collaboration scheme between universitiesgovernment-the business sector. The local Government of Sumedang Regent should support any necessary policies, mainly in infrastructure.

\section{Acknowledgment}

The authors would like to thanks Universitas Padjadjaran for the 2018 Research Grant. An appreciation and thanks to Pager Kamulyan Farmers Group and Chrysanthemum Women 
Farmers Group, informants from Genteng Village Government Officials, local leaders, and various vital persons as informants for providing information for the research's analysis.

\section{Declaration of Conflicting Interests}

The authors have declared no potential conflicts of interest concerning the research, authorship, and/or publication of this article.

\section{References}

Ahuja, V. (2011). Cyber extension: A convergence of ICT and agricultural development. Global Media Journal, Indian Edition, 2(2), 1-8.

Akgün, A. A., Baycan, T., \& Nijkamp, P. (2014). Rethinking on Sustainable Rural Development. European Planning Studies, 23(4), 678-692. https:// doi.org/10.1080/09654313.2014.945813

Anderson, A., Loomba, P., Orajaka, I., Numfor, J., Saha, S., Janko, S., ... Larsen, R. (2017). Empowering Smart Communities: Electrification, Education, and Sustainable Entrepreneurship in IEEE Smart Village Initiatives. IEEE Electrification Magazine, 5(2), 616. https:/ / doi.org/10.1109/mele.2017.2685738

Bahtiar, A. R., Segara, A. J. T., \& Suyoto, S. (2020). Design of Smart Gamification In Village Tourism: An Indonesian Case Study. International Journal of Engineering Pedagogy (IJEP), 10(1), 82. https:/ / doi.org/10.3991/ijep.v10i1.11522

Baruah, A., \& Mohan, M. (2018). The Farmers' View towards the Use of Information and Communication Technology in Agriculture: A Study among Farmers in the NER (NorthEastern Region) of India. Journal of Emerging Technologies and Innovative Research, 5(11), 17-23. Retrieved from http:/ / www.jetir.org/view?paper=JETIRL006005

Chatterjee, M., \& Mitchell, J. K. (2013). The Scope for Broadening Climate-Related Disaster Risk Reduction Policies in Mumbai. The Professional Geographer, 66(3), 363-371. https:/ / doi.org/10.1080/00330124.2013.821724

de Roest, K., Ferrari, P., \& Knickel, K. (2018). Specialisation and economies of scale or diversification and economies of scope? Assessing different agricultural development $\begin{array}{lllll}\text { pathways. Journal of } & \text { Rural }\end{array}$ https:// doi.org/10.1016/j.jrurstud.2017.04.013

Fatimah, S., \& Prawita, D. (2015). Attitude towards Cyber Extension as Information Source among Farmers: Case of Mujagi and Rancasari Farmers Groups in West Java. Proceedings ASEAN ICT4SRD 2015, 29-34. Kuala Lumpur, Malaysia: Universiti Teknologi Malaysia.

Garcia-Alvarez-Coque, J.-M., Roig-Tierno, N., Sanchez-Garcia, M., \& Mas-Verdu, F. (2020). Knowledge Drivers, Business Collaboration and Competitiveness in Rural and Urban Regions. Social Indicators Research, 1-19. https:/ / doi.org/10.1007/s11205-020-02478-6

Guzal-Dec, D. (2018). Intelligent Development of the Countryside - The Concept of Smart Villages: Assumptions, Possibilities and Implementation Limitations. Economic and Regional Studies / Studia Ekonomiczne $i$ Regionalne, 11(3), 32-49. https:// doi.org/10.2478/ers-2018-0023

Kamarudin, S., Omar, S. Z., Bolong, J., Osman, M. N., \& Mahamed, M. (2019). ICT Development of Community in Rural Areas. International Journal of Academic Research in Business and Social Sciences, 9(9), 118-126. https:// doi.org/10.6007/ijarbss/v9-i9/6273

Kantor Desa Genteng. (2018). Profil Desa Genteng, Kecamatan Sukasari, Kabupaten Sumedang, Provinsi Jawa Barat.

Copyright (C) 2020. Owned by Author(s), published by Society. This is an open-access article under the CC-BY-NC-SA license. 
Lam, S., \& Ho, K. F. (2010). Personal development empowerment through ICT in corporate learning: A case study of two developing cities in China. International Journal of Advanced Corporate Learning (IJAC), 3(2), 14-20. https:/ / doi.org/10.3991/ijac.v3i2.1280

Liu, Z., \& Zhang, W. (2011). Which Factors Affect Farmers' Willingness for Soil Testing Technology Adoption: A Case Study of Tai Lake Watershed, China.

Nidumolu, U., Adusumilli, R., Tallapragada, C., Roth, C., Hochman, Z., Sreenivas, G., ... Ratna Reddy, V. (2020). Enhancing adaptive capacity to manage climate risk in agriculture through community-led climate information centres. Climate and Development, 1-12. https:/ / doi.org/10.1080/17565529.2020.1746230

Okwu, O. J., \& Umoru, B. I. (2009). A study of women farmers agricultural information needs and accessibility: a case study of Apa local government area of Benue state, Nigeria. African Journal of Agricultural Research,4(12), 1404-1409. Retrieved from https:/ / academicjournals.org/journal/ AJAR/article-abstract/06B9F0C31367

Phiri, H., Kunda, D., \& Phiri, J. (2018). An IoT Smart Broiler Farming Model for Low Income Farmers. International Journal of Recent Contributions from Engineering, Science $\mathcal{E}$ IT (IJES), 6(3), 95. https://doi.org/10.3991/ijes.v6i3.9287

Pramanik, J. , Sarkar, B. , \& Kandar, S. (2017). Impact of ICT in Rural Development: Perspective of Developing Countries. American Journal of Rural Development, 5(4), 117-120. Retrieved from http:/ / pubs.sciepub.com/ajrd/5/4/5/

Rubin, A., \& Babbie, R. (2010). Research Methods for Social Work. Boston, United States: Cengage Learning.

Sachs, W., \& George, S. (2015). Planet Dialectics: Explorations in Environment and Development (Critique Influence Change) (2nd ed.). London, United Kingdom: Zed Books.

Shcherbina, E., \& Gorbenkova, E. (2018, June). Smart city technologies for sustainable rural development. In IOP Conference Series: Materials Science and Engineering (Vol. 365, No. 2, p. 022039). IOP Publishing. https:// doi.org/10.1088/1757-899x/365/2/022039

Shukla, P. Y. (2016). The Indian smart village: Foundation for growing India. International Journal of Applied Research,2(3), 72-74. Retrieved from https://www.allresearchjournal.com/archives/2016/vol2issue3/PartB/2-2-111.pdf

Somwanshi, R., Shindepatil, U., Tule, D., Mankar, A., Ingle, N., Rajamanya, G. B. D. V., \& Deshmukh, A. (2016). Study and development of village as a smart village. International Journal of Scientific $\mathcal{E}$ Engineering Research,7(6), 395-408. Retrieved from https:/ / www.ijser.org/onlineResearchPaperViewer.aspx?Study-and-development-ofvillage-as-a-smart-village.pdf

Sumedang Tandang. (n.d.). Desa Genteng. Retrieved from http:/ / sumedangtandang.com/direktori/detail/desa-genteng.htm

Syarifuddin. (2010). Literasi Teknologi Informasi dan Komunikasi Masyarakat Pedesaan. Jurnal Studi Komunikasi Dan Media, (19), 153-164.

Tetteh, B. K. D., Ansah, I. G. K., Donkoh, S. A., Appiah-Twumasi, M., Avornyo, F. K., Shaibu, M. T., ... Akufo, N. M. (2019). Perceptions of weather variability and climate change on goat producers' choice of coping and adaptation strategies: evidence from climate-smart and non-climate-smart villages in the Jirapa and Lawra districts. Climate and Development, 12(7), 614-625. https:/ / doi.org/10.1080/17565529.2019.1664975

Tu, S., Long, H., Zhang, Y., Ge, D., \& Qu, Y. (2018). Rural restructuring at village level under rapid urbanization in metropolitan suburbs of China and its implications for innovations in land use policy. Habitat International, 77, 143-152. https:/ / doi.org/10.1016/j.habitatint.2017.12.001

Copyright (C 2020. Owned by Author(s), published by Society. This is an open-access article under the CC-BY-NC-SA license. 
Vaishar, A., \& Št́astná, M. (2019). Smart Village and Sustainability. Southern Moravia Case Study. European Countryside, 11(4), 651-660. https:/ / doi.org/10.2478/euco-2019-0036

van Gevelt, T., Canales Holzeis, C., Fennell, S., Heap, B., Holmes, J., Hurley Depret, M., ... Safdar, M. T. (2018). Achieving universal energy access and rural development through smart villages. Energy for Sustainable Development, 43, 139-142. https:// doi.org/10.1016/j.esd.2018.01.005

Vignesh, R. K., \& Priyan, R. S. (2018). Development of village as a smart village - A critical review. International Journal of Advance Research, Ideas and Innovations in Technology, 4(6), 237-240. Retrieved from https://www.ijariit.com/manuscript/development-of-villageas-a-smart-village-a-critical-review/

Viswanadham, N., \& Vedula, S. (2010, September). Design of Smart Villages: India Moving up the Service Chain. Hyderabad, India: The Centre for Global Logistics and Manufacturing Strategies, Indian School of Business. Retrieved from https://gtl.csa.iisc.ac.in/nv/Mypublications/C/z.pdf

Zavratnik, V., Kos, A., \& Stojmenova Duh, E. (2018). Smart Villages: Comprehensive Review of Initiatives and Practices. Sustainability, 10(7), 2559. https://doi.org/10.3390/su10072559

\section{About the Authors}

1. Sri Fatimah, obtained her Doctoral degree from Universiti Kebangsaan Malaysia, in 2004. The author is an Assistant Professor at the Department of Agricultural Socio-Economics, Faculty of Agriculture, Universitas Padjadjaran, Indonesia.

E-Mail: $\underline{\text { rri.fatimah@unpad.ac.id }}$

2. Mochamad Gunardi Judawinata, obtained his Diplôme d'Études Approfondies or D.E.A (Master of Advanced Studies) from Université Paris 1 Panthéon-Sorbonne, France, in 1995. The author is an Assistant Professor at the Department of Agricultural Socio-Economics, Faculty of Agriculture, Universitas Padjadjaran, Indonesia.

E-Mail: gunardi.judawinata@unpad.ac.id

3. Mochamad Nursiyam Barkah, obtained his Master degree in Geology Engineering from Universitas Padjadjaran, Indonesia, in 2013. The author is an Assistant Professor at the Department of Applied Geology, Faculty of Geology Engineering, Universitas Padjadjaran, Indonesia.

E-Mail: $\underline{\text { m.nursiyam@unpad.ac.id }}$

4. Lucyana Trimo, obtained her Doctoral degree in Agricultural Science from Universitas Padjadjaran, Indonesia, in 2012. The author is an Assistant Professor at the Department of Agricultural Socio-Economics, Faculty of Agriculture, Universitas Padjadjaran, Indonesia. E-Mail: lucyana.trimo@unpad.ac.id

5. Yosini Deliana, obtained her Doctoral degree from Universitas Padjadjaran, Indonesia, in 2004. The author is a Professor at the Department of Agricultural Socio-Economics, Faculty of Agriculture, Universitas Padjadjaran, Indonesia.

E-Mail: deliana@unpad.ac.id

Copyright (C 2020. Owned by Author(s), published by Society. This is an open-access article under the CC-BY-NC-SA license. https://doi.org/10.33019/society.v8i2.264

676 